\title{
ANTESEDEN SENSITIVITAS ETIKA AUDITOR PAJAK
}

\section{Tony Wijaya \& Nerys Lourensius L.T}

STIE IEU Yogyakarta

ABSTRACT. This research aims to test the influence of modern tax administration to tax auditor ethical sensitivity in DJP (Direktorat Jenderal Pajak) Jakarta Regional Office. Sample in this research is tax auditor in DJP Jakarta Regional Office. Sample selection is performed based on purposive sampling, there are 182 responder which have been fulfilling the conditions needed. Data collecting conducted by disseminating questionare. The analyzed use the multiple regression. Result of research shows that modern tax administration consist of officer ethics code, etics committee and renumeration have influence to tax auditor ethical sensitivity in DJP Jakarta Regional Office. The result shows that the effects of modern tax administration consist of officer ethics code, etics committee and renumeration to ethical sensitivity has $R$ Square of 0,321 or $32,1 \%$.

Keywords: Modern tax administration, Ethical sensitivity, Officer ethics code, Ethics committee, renumeration

\section{PENDAhUlUAN}

Tuntutan profesi akuntan Indonesia pada masa yang akan datang menghadapi tantangan yang semakin berat, untuk itu diperlukan kesiapan yang menyangkut profesionalisme profesi. Profesionalisme suatu profesi diwujudkan dalam sikap dan tindakan etis. Sikap dan tindakan etis akuntan sangat menentukan posisinya di masyarakat pengguna jasa profesionalnya. Bagi profesi akuntan, sikap dan tindakan etis akan menentukan keberadaan akuntan dalam peta persaingan antara rekan profesi akuntan dari negara lain (Ludigdo dan Machfoedz, 1999).

Radtke (2000) menyatakan bahwa pendidikan etika dalam akuntansi didasarkan pada suatu premis bahwa pengembangan moral dapat ditingkatkan melalui proses pendidikan. Ini dikuatkan oleh berbagai riset etika dalam bidang akuntansi seperti: identifikasi tujuan pendidikan etika dalam akuntansi; masalah-masalah etika dan kebutuhan untuk mengakses outcome pengajaran etika dalam akuntansi. Studi tentang etika telah banyak dilakukan baik di luar negeri maupun di dalam negeri (Ameen et 
al., 1996; Radtke, 2000; Komsiyah dan Indriantoro, Rustiana, 2003). Subyek yang menjadi responden bervariasi dari kelompok profesional sampai pada kelompok mahasiswa. Hasil dari para peneliti tersebut bervariasi, dengan temuan bahwa ada perbedaan tentang etika diantara berbagai kelompok dan temuan sebaliknya bahwa tidak ada perbedaan tentang etika.

Etika akuntan telah menjadi issue yang sangat menarik. Di Amerika Serikat issue ini antara lain dipicu oleh terjadinya crash pasar modal tahun 1987 (Chua et al, 1994). Sedangkan di Indonesia, isu ini berkembang seiring dengan terjadinya beberapa pelanggaran etika yang terjadi, baik yang dilakukan oleh akuntan publik, akuntan intern, maupun akuntan pemerintah (Machfoedz, 1999). Untuk kasus akuntan publik, beberapa pelanggaran etika ini dapat ditelusuri dari laporan Dewan Kehormatan IAI dalam laporan pertanggungjawaban pengurus IAI periode 1990-1994 yang menyebutkan adanya 21 kasus yang melibatkan 53 KAP (Husada, 1996). Secara historis, akuntan merasa lebih etis dibanding dengan profesi-profesi lain, padahal isu pelanggaran etika yang dilakukan auditor semakin nyata terjadi.

Ini seharusnya tidak terjadi apabila setiap akuntan mempunyai pengetahuan, pemahaman, dan menerapkan etika secara memadai dalam pelaksanaan pekerjaan profesionalnya. Pekerjaan seorang profesional harus dikerjakan dengan sikap profesional pula, dengan sepenuhnya melandaskan pada standar moral dan etika tertentu. Dengan sikap profesionalnya, akuntan akan mampu menghadapi berbagai tekanan yang dapat muncul dari dirinya sendiri ataupun pihak eksternal. Kemampuan seorang profesional untuk dapat mengerti dan peka terhadap persoalan etika juga sangat dipengaruhi oleh lingkungan dimana dia berada. Menurut Hunt dan Vitell (1986) kemampuan seorang profesional sangat dipengaruhi oleh lingkungan budaya atau masyarakat dimana profesi terrsebut berada, lingkungan profesinya, lingkungan organisasi atau tempat kerja serta pengalaman pribadinya. Sikap masyarakat yang pasif, sistem pengawasan yang masih lemah dari organisasi, kerjasama yang tidak sehat turut mempengaruhi perilaku etika auditor. Dalam hal ini, Sudibyo (1995) menyatakan bahwa dunia pendidikan akuntansi juga mempunyai pengaruh yang besar terhadap perilaku etika akuntan (Khomsiyah dan Indriantoro, 1997). Sikap pandang dan kepekaan terhadap etika yang dimiliki seseorang berinteraksi dengan nilai-nilai yang ditemuinya dalam profesi akan menghasilkan suatu sikap dan orientasi etika yang baru yang nantinya akan menentukan tindakan atau keputusannya sebagai auditor dalam masalah etika.

Perkembangan issue etika juga menjadi bagian dari tax auditor di Kantor Pelayanan Pajak. Persepsi negatif telah melekat pada sejumlah tax auditor di Kantor Pelayanan Pajak yang diduga telah melakukan tindakan kolusi dengan wajib pajak yang tidak patuh. Perilaku ini cenderung didorong oleh 
perilaku tidak etis tax auditor tersebut. Berbagai upaya telah dilakukan oleh pemerintah guna meminimalkan perilaku tersebut antara lain dengan melakukan reformasi di bidang administrasi dengan menerapkan sistem administrasi pajak modern yang sudah digulirkan sejak tahun 2002 pada Kantor Pelayanan Pajak WP Besar Satu dan Kantor Pelayanan Pajak WP Besar Dua. Pada tahun 2004 sistem administrasi pajak modern diterapkan pada Kantor Pelayanan Pajak di lingkungan Kantor Wilayah DJP Jakarta Khusus dan pada tahun 2008 direncanakan sistem administrasi pajak modern telah diterapkan diseluruh Kantor Pelayanan Pajak di Indonesia.

Tujuan diterapkannya sistem administrasi pajak modern adalah mengamankan penerimaan Negara dari sektor pajak dan pencitraan Direktorat Jenderal Pajak yang positip. Secara eksternal pemerintah berusaha keras untuk meningkatkan kesadaran dan kepatuhan masyarakat dalam membayar pajak. Wajib Pajak patuh bukan berarti wajib pajak yang membayar dengan nominal besar melainkan wajib pajak yang mengerti mengenai hak dan kewajibannya dalam bidang perpajakan serta memenuhi kriteria-kriteria tertentu. Berdasarkan informasi yang ada ternyata jumlah wajib pajak yang tergolong patuh masih sangatlah minim. Pada provinsi DKI Jakarta jumlah wajib pajak badan yang tergolong patuh hanya sebesar 262 dari tiga juta wajib pajak yang terdaftar, ini berarti hanya 0,000873\% (Bisnis Indonesia, 27 Februari 2004). Sedangkan di kota Palembang pada lingkungan Kantor Pelayanan Pajak Ilir hanya 50 wajib pajak badan yang terdaftar (Sriwijaya Post, 25 Maret 2004). Minimnya tingkat kepatuhan wajib pajak antara lain adalah pengetahuan perpajakan yang dimiliki oleh wajib pajak, persepsi wajib pajak terhadap petugas pajak, dan beratnya syaratsyarat untuk menjadi wajib pajak patuh (Bisnis Indonesia, 27 Februari 2004). Secara internal pemerintah berusaha meningkatkan SDM petugas pajak melalui pendidikan dan pelatihan, serta mengupayakan perbaikan perilaku etis petugas pajak dengan remunerasi yang lebih baik dan disertai dengan menerapkan kode etik pegawai.

Dengan sistem administrasi pajak modern diyakini praktek-praktek KKN pajak melalui jalur apapun bisa diantisipasi. Penerapan sistem administrasi pajak modern diharapkan dapat memperbaiki citra Direktorat Jenderal Pajak pada umumnya dan tax auditor pada khususnya. Penelitian ini bertujuan mengetahui pengaruh sistem administrasi pajak modern yang dilihat dari penerapan kode etik pegawai, komite kode etik dan remunerasi terhadap sensitivitas etika tax auditor di lingkungan Kantor Wilayah DJP Jakarta khusus.

\section{Sistem Administrasi Pajak Modern}

Visi Direktorat Jenderal Pajak adalah menjadi model pelayanan masyarakat yang menyelenggarakan sistem dan manajemen perpajakan kelas dunia, yang dipercaya dan dibanggakan masyarakat. Untuk mewujudkan visi tersebut Ditjen Pajak mengembangkan beberapa misi 
dibidang fiskal, ekonomi, politik dan kelembagaan. Misi Ditjen Pajak di bidang fiskal adalah menghimpun penerimaan dalam negeri dari sektor pajak yang mampu menunjang kemandirian pembiayaan berdasarkan UU Perpajakan tingkat efektivitas dan efisiensi yang tinggi (Direktorat Jenderal Pajak, 2006). Dalam rangka pelaksanaan dari rencana pembangunan nasional jangka menengah 2004-2009, Ditjen Pajak telah memfokuskan diri pada pembangunan sistem administrasi pajak modern. Sistem administrasi pajak modern berupaya mengantisipasi praktek-praktek KKN pajak dalam rangka mewujudkan good governance.

Sistem administrasi pajak modern selain memperbaiki secara total pelayanan perpajakan yang ada selama ini juga mampu mendukung optimalisasi pembangunan bank data pajak menunju bank data nasional yang dibutuhkan sebagai dasar dalam penerapan single identity number. Sistem administrasi pajak modern diharapkan mampu memperbaiki citra, memperbaiki kinerja organisasi dan memperbaiki sumber daya manusia.

Karakteristik sistem administrasi pajak modern ditandai dengan restrukturisasi sistem berupa:

1. Struktur organisasi berdasarkan fungsi - debirokratisasi untuk pelayanan.

2. Penggabungan dari KPP, KARIKPA dan KPPBB - melayani semua jenis pajak.

3. Pemeriksaan hanya di KPP dengan konsep spesialisasi

4. Keberatan dan Penyidikan dilakukan di Kanwil

5. Account Representatives (AR) - pengawasan dan pelayanan dengan konsep spesialisasi.

6. Help Desk dengan teknologi knowledge base pada TPT (service counter)

7. Menggunakan sistem komunikasi dan teknologi informasi terkini

8. SDM yang berkualitas tinggi

9. Penerapan kode etik pegawai yang pelaksanaannya diawasi oleh komite kode etik pegawai

10. Sistem penggajian yang lebih baik

Secara khusus sistem administrasi pajak modern dibagi menjadi 3 kelompok besar yaitu:

\section{Penerapan Kode Etik Pegawai}

Dalam sistem administrasi perpajakan modern, kode etik pegawai DJP dilaksanakan berdasarkan :

1. PP No.30 tahun 1980 tentang Disiplin Pegawai Negeri Sipil

2. PP No.42 tahun 2004 Pembinaan Jiwa Korps dan Kode Etik PNS

3. KeputusanMenteriKeuanganNomor222/KMK.03/2002tentangKodeEtik Pegawai di Lingkungan DJP stdt dengan KMK No.382/KMK.03/2002 
4. Keputusan MenteriKeuangan Nomor 223/KMK.03/2002 tentang Susunan, Tugas dan Wewenang Komite Kode Etik Pegawai di Lingkungan DJP.

5. Peraturan Menkeu No.32/PMK.03/2007 tentang Perubahan Kedua atas KMK No.222/KMK.03/2003 tentang Kode Etik Pegawai di Lingkungan DJP.

6. Peraturan Menkeu No.33/PMK.03/2007 tentang Pemberlakuan Kode Etik Pegawai di Lingkungan KPDJP dan Instansi Vertikal DJP.

Kode Etik Pegawai DJP mencakup 20 butir kewajiban pegawai DJP dan 12 larangan pegawai DJP. Jika melihat definisinya, menurut A.S. Hornby (1968), Kode Etik terdiri dari kata code dan conduct. Kata code sendiri mempunyai tiga arti yaitu: pertama collection of law arranged in a system, kedua system of rules and principles that has been accepted by society or a class or group of people, serta ketiga system of signs. Sedangkan kata conduct mempunyai dua arti yaitu: pertama behavior (moral) dan kedua manner of directing or managing affairs. Oleh karena itu dengan Kode Etik ini diharapkan dapat:

1. Mendefinisikan tingkah laku pegawai DJP yang dapat diterima semua pihak,

2. Memberikan batasan yang jelas akan hak dan kewajiban para pegawai DJP maupun Wajib Pajak,

3. Mendorong diwujudkannya pelayanan dengan kualifikasi atau standar yang tinggi,

4. Memberikan kebanggaan kepada pegawai DJP akan predikatnya sebagai pelayan masyarakat,

5. Memberikan citra yang baik kepada Direktorat Jenderal Pajak di mata stakeholders.

Penting untuk digarisbawahi bahwa pemberlakuan Kode Etik memerlukan akseptansi dan komitmen dari semua pihak baik dari organisasi, pimpinan, pegawai maupun Wajib Pajak sebagai stakeholders DJP, sehingga keberhasilan implementasinya akan sangat ditentukan oleh pihak-pihak tersebut.

\section{Komite Kode Etik}

Pelanggaran terhadap kode etik pegawai merupakan pelanggaran disiplin pegawai dan atau pelanggaran hukum lainnya, dimana pengawasan dalam pelaksanaannya dilakukan oleh suatu Komite Kode Etik Pegawai DJP yang dibentuk berdasarkan keputusan Menteri Keuangan No.223/ KMK.03/2002 tanggal 14 Mei 2002 tentang Susunan, Tugas dan Wewenang Komite Kode Etik Pegawai DJP.

Membangun komite yang efektif tidak boleh terlepas dari kacamata penerapan prinsip good corporate governance secara keseluruhan yang independency, transparency dan disclosure, accountability, responsibility 
dan fairness menjadi landasan utama dalam menjalankan organisasi. Komite harus bersikap adil dalam pengambilan keputusan, hal ini ditujukan kepada semua pihak, terutama dalam penelaahan terhadap kesalahan asumsi maupun pelanggaran terhadap standart operasional prosedur.

\section{Remunerasi (Sistem Penggajian)}

Modernisasi di kantor DJP akan diikuti dengan peningkatan gaji pegawai. Konsep modernisasi meliputi pemanfaatan sistem performance management untuk pengembangan karier dan pemberian insentif. Reward pada umumnya diwujudkan dalam bentuk uang, oleh karena uang adalah alat penukar yang paling mudah, merupakan alat standar dalam lalulintas perekonomian negara atau antar negara. Guzzetta (1996), menyebutkan bahwa sebuah program reward yang efektif memiliki empat komponen dasar yaitu, kompensasi dasar pemberi layanan, struktur tabungan resiko, defisit yang menutupi resiko dan kompensasi reward.

Ada macam-macam cara untuk memberikan balas jasa kepada karyawan untuk pekerjaan yang dilaksanakan. Pada pokoknya balas jasa seorang karyawan dapat didasarkan pada waktu, hasil pekerjaan, serta gabungan waktu dan hasil kerja. Cara berdasarkan waktu, berwujud gaji dengan jumlah tertentu yang dibayarkan per bulan kepada seorang karyawan. Cara ini digunakan bilamana sulit atau mahal biayanya untuk mengukur hasil pekerjaan karyawan yang bersangkutan. Cara berdasarkan hasil pekerjaan, diwujudkan dalam bentuk pembayaran yang dibayarkan berdasarkan besar kecilnya hasil pekerjaan. Cara berdasarkan gabungan waktu dan hasil kerja, diwujudkan dalam bentuk kombinasi antara waktu dengan hasil pekerjaan yang dihasilkan karyawan. Misalnya: gaji khusus merupakan balas jasa untuk waktu saja, sedangkan reward diberikan untuk pekerjaan yang dilaksanakan dengan baik. Dalam Modernisasi di kantor pusat DJP juga diikuti dengan pemberian tunjangan kegiatan tambahan untuk pegawai kantor wilayah direktorat jenderal pajak. Pemberian tunjangan kegiatan tambahan diberikan berdasarkan kinerja pegawai.

\section{HIPOTESIS \& MODEL PENELITIAN}

Kode etik diberlakukan sebagai pedoman perilaku anggota dalam organisasi (Chua, 1994). Dalam zaman modern, selain profesi medis, ada banyak profesi lagi yang memiliki sebuah kode etik khusus, misalnya para pengacara, wartawan, akuntan, insinyur, dan psikolog. Banyak karyawan yang berkecimpung di bidang bisnis, terikat dengan salah satu kode etik profesi. Pembuatan kode etik merupakan strategi untuk melembagakan etika dalam struktur dan kegiatan organisasi. Jika organisasi memiliki kode etik sendiri, ia mempunyai beberapa kelebihan dibandingkan dengan perusahaan yang tidak memilikinya. Kode etik dapat menjelaskan bagaimana anggota organisasi menilai tanggung jawab sosialnya. Kode etik 
berfungsi dalam merumuskan standar etis yang jelas dan tegas untuk semua karyawan dan jangkauan tanggung jawab sosial perusahaan (Bertens, 2000). Munuera dan Roman (2004) menemukan adanya konsekuensi dari kode etik terhadap perilaku kerja karyawan. Dengan demikian semakin baik kode etik pegawai maka semakin tinggi sensitivitas etika pegawai. Dengan demikian hipotesis yang diajukan dalam penelitian ini adalah:

H1: Kode etik pegawai berpengaruh positif terhadap Sensitivitas Etika Tax auditor di Lingkungan Kantor Wilayah DJP Jakarta khusus.

Kode etik pegawai DJP disusun sebagai pedoman bagi pegawai pajak untuk berlaku sesuai kode etik yang ditentukan sekaligus sebagai penilaian atas tindakan pegawai DJP. Komite Kode Etik disusun sebagai pengawas atas ketaatan pegawai DJP terhadap kode etik pegawai, komite berperan sebagai controller atas tindakan etis pegawai pajak. Alleyne et al (2006) mengemukakan bahwa komite audit berperan dalam pengawasan auditor dalam melakukan audit sehingga mencegah auditor untuk melakukan pelanggaran-pelanggaran. Dengan demikian semakin baik pelaksanaan sistem adminitrasi pajak modern maka semakin tinggi Sensitivitas etika tax auditor pada Lingkungan Kantor DJP. Dengan demikian hipotesis yang diajukan dalam penelitian ini adalah:

H2: Komite kode etik dan Remunerasi berpengaruh positif dan signifikan terhadap Sensitivitas etika Tax auditor di Lingkungan Kantor Wilayah DJP Jakarta khusus.

Sistem administrasi pajak modern merupakan bentuk antisipasi terhadap tindakan tidak etis pegawai DJP khususnya di lingkungan Kantor Wilayah DJP Jakarta khusus. Tindakan tidak etis ditunjukkan dengan gejala untuk tidak bertindak etis atau sensitivitas etika dalam bekerja. Zekos (2004) mengemukakan bahwa tindakan kolusi didasari oleh tindakan-tindakan tidak etis pelakunya. Etika merupakan sumber moral dalam berperilaku, individu yang tidak beretika cenderung melakukan tindakan kolusi dibandingkan yang memiliki etika. Sejalan dengan usaha untuk mencegah resiko godaan pemenuhan penghasilan, dalam sistem administrasi pajak modern ditetapkan remunerasi berupa pemberian tunjangan kegiatan tambahan dan diharapkan tax auditor di Lingkungan Kantor Wilayah DJP Jakarta Khusus akan berlaku etis. Santos et al (2004) menemukan bahwa pemberian imbalan atau tunjangan akan meningkatkan kinerja pegawai karena imbalan atau tunjangan akan mendorong pegawai untuk bertindak secara etis. Roman \& Munuera (2004) dalam penelitian juga menemukan bahwa semakin baik sistem kompensasi yang diberlakukan dalam organisasi akan meningkatkan etika pegawai. Dengan demikian hipotesis yang diajukan dalam penelitian ini adalah:

H3: Remunerasi berpengaruh positif dan signifikan terhadapSensitivitas etika Tax auditor di Lingkungan Kantor Wilayah DJP Jakarta khusus. 


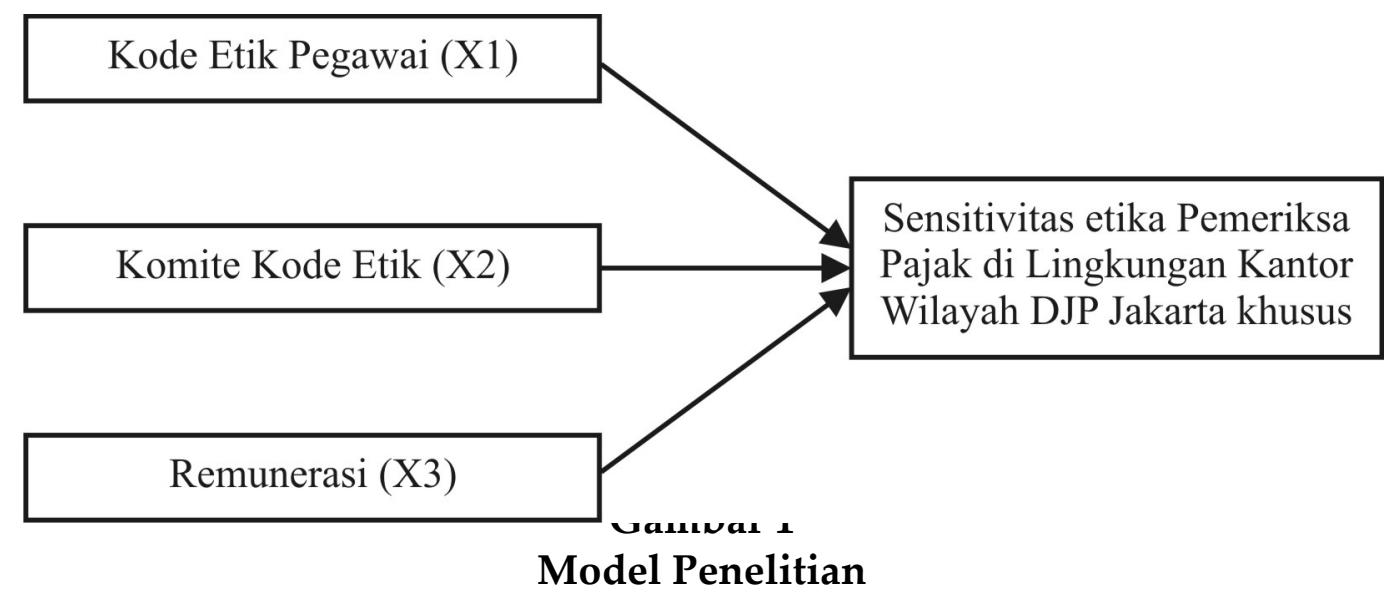

\section{METODE PENELITIAN}

Populasi dalam penelitian ini adalah tax auditor di Lingkungan Kantor Wilayah DJP Jakarta khusus. Jumlah populasi yang cukup besar dan bervariasi berdasarkan karaktreristiknya. Akibatnya jumlah sampel yang perlu diambil dalam kondisi demikian ditentukan dengan karakteristik tertentu (Sekaran, 2003). Metode pengambilan sampel dilakukan dengan metode non-probability sampling khususnya metode purposive sampling dengan karakteristik akuntan dalam bidang pemeriksaan pajak serta memiliki masa kerja di atas 3 tahun.

Sumber data merupakan subyek dari data yang dapat diperoleh untuk penelitian. Sumber data yang digunakan dalam penelitian ini adalah sumber data primer. Metode yang digunakan dalam pengumpulan data dalam penelitian ini adalah metode kuesioner. Dalam penelitian ini seluruh instrumen diukur dengan 5 skala sikap Likert, yang nilainya dimulai dari angka 1 = sangat tidak setuju sampai dengan angka 5 = sangat setuju .

Variabel dalam penelitian ini terdiri dari variabel bebas dan variabel terikat. Variabel terikat (Y) dalam penelitian ini adalah sensitivitas etika. Sensitivitas etika yang dimaksud dalam penelitian ini adalah ciri-ciri tindakan yang mendeteksi kemungkinan dalam berperilaku etis sebagai gambaran atau proksi dari tindakan etis tax auditor. Variabel ini diukur dengan indikator kewajaran dalam menerima hadiah, penggunaan fasilitas kantor, imbalan dari wajib pajak, penggunaan wewenang dan kunjungan dari wajib pajak. Variabel bebas $(X)$ dalam penelitian ini adalah sistem administrasi pajak modern yang terdiri dari kode etik pegawai (X1) yaitu aturan yang mengatur tingkah laku pegawai pajak berbentuk kewajiban dan larangan dari pegawai pajak dalam menjalankan tugas yang diukur dengan indikator bersikap jujur dan lugas dalam menjalankan tugas, berpenampilan dan berbusana sesuai dengan tuntutan tugas, berkewajiban memberikan informasi yang jelas lengkap dan benar kepada Wajib Pajak, 
melaporkan secara tertulis jika ada situasi konflik kepentingan, melaporkan secara tertulis kepada atasan apabila mengetahui adanya pelanggaran/ penyimpangan. Komite kode etik (X2) yaitu pengawasan dari komite pada pegawai dimana pengawasan dalam pelaksanaannya dilakukan oleh suatu Komite Kode Etik Pegawai DJP yang dibentuk berdasarkan keputusan Menteri Keuangan No.223/KMK.03/2002 tanggal 14 Mei 2002 tentang Susunan, Tugas dan Wewenang Komite Kode Etik Pegawai DJP, variabel ini diukur dengan indikator komite menerima pengaduan atas pelanggaran Kode Etik, berwenang memanggil dan meminta keterangan kepada pegawai, meminta keterangan dari pihak lain dalam rangka penelitian atas dugaan pelanggaran Kode Etik, berwenang mengusulkan pemberian sanksi, melakukan penelitian atas dugaan pelanggaran, menyerahkan berita acara penelitian atas pelanggaran. Remunerasi (X3) yaitu pemberian tunjangan kegiatan tambahan untuk pegawai kantor wilayah direktorat jenderal pajak. Pemberian tunjangan kegiatan tambahan diberikan berdasarkan kinerja pegawai. Variabel ini diukur dengan indikator tunjangan tambahan untuk pegawai DJP adil, tunjangan tambahan yang saya terima sesuai dengan tanggung jawab, tunjangan tambahan akan meningkatkan kinerja, meningkatkan disiplin kerja dan kepatuhan.

\section{PENGUJIAN INSTRUMEN PENELITIAN}

\section{Uji Validitas}

Uji validitas dilakukan untuk mengetahui apakah suatu instrumen alat ukur telah menjalankan fungsi ukurnya. Menurut Sekaran (2003) validitas menunjukkan ketepatan dan kecermatan alat ukur dalam melakukan fungsi ukurnya. Suatu skala pengukuran disebut valid bila ia melakukan apa yang seharusnya dilakukan dan mengukur apa yang seharusnya diukur. Pada penelitian ini validitas diuji meng 7 gunakan factors analysis (Cooper dan Schindler, 2001). Sebuah faktor dikatakan valid apabila memiliki factor loading berada pada kisaran 0.40 ke atas (Chia dalam Sekaran, 2003).

Tabel 1.

\begin{tabular}{|c|c|}
\hline Hasil Uji Validitas & Variabel Factor Loading \\
\hline Kode Etik Pegawai & \\
\hline P1 & 0,872 \\
\hline P2 & 0,674 \\
\hline P3 & 0,709 \\
\hline P4 & 0,741 \\
\hline P5 & 0,927 \\
\hline P6 & 0,729 \\
\hline P7 & 0,797 \\
\hline Komite Kode Etik & \\
\hline
\end{tabular}




\begin{tabular}{|c|c|}
\hline Hasil Uji Validitas & Variabel Factor Loading \\
\hline P8 & 0,890 \\
\hline P9 & 0,836 \\
\hline P10 & 0,701 \\
\hline P11 & 0,912 \\
\hline P12 & 0,912 \\
\hline P13 & 0,793 \\
\hline Remunerasi & \\
\hline P14 & 0,908 \\
\hline P15 & 0,901 \\
\hline P16 & 0,904 \\
\hline P17 & 0,951 \\
\hline Sensitivitas etika & \\
\hline E1 & 0,787 \\
\hline E2 & 0,528 \\
\hline E3 & 0,736 \\
\hline E4 & 0,723 \\
\hline E5 & 0,695 \\
\hline
\end{tabular}

Sumber: Data primer diolah, 2010

Berdasarkan hasil uji validitas menggunakan analisis faktor dapat diketahui bahwa seluruh variabel dalam penelitian ini dinyatakan valid karena memiliki factor loading $>0,4$.

\section{Uji Reliabilitas}

Pengujian terhadap reliabilitas ditujukan untuk memastikan bahwa responden benar-benar konsisten dengan jawaban yang diberikan dalam kuesioner tersebut. Pengujian reliabilitas instrumen di $\urcorner$ laku $\urcorner$ kan dengan meng 7 gunakan croncbach alpha dengan rule of thumb nilai 0,6 (Nunnaly, 1979) yang mana nilai ini harus di atas nilai $r$ untuk dikatakan reliabel.

Tabel 2.

Hasil Uji Internal Consistency Reliability

\begin{tabular}{|l|c|c|c|}
\hline \multicolumn{1}{|c|}{ Variabel } & Alpha & Cronbach alpha & Reliabilitas \\
\hline Kode etik pegawai & 0,7854 & 0,6 & Reliabel \\
\hline Komite kode etik & 0,9598 & 0,6 & Reliabel \\
\hline Remunerasi & 0,6178 & 0,6 & Reliabel \\
\hline Sensitivitas etika & 0,7615 & 0,6 & Reliabel \\
\hline
\end{tabular}

Sumber: Data primer diolah, 2010 
Berdasarkan uji reliabilitas menggunakan Cronbach Alpha, semua item yang dikumpulkan melalui instrumen penelitian terbukrti reliabel atau handal karena alpha yang diperoleh lebih besar dari 0.6.

\section{Teknik Pengujian Asumsi Klasik}

Ada tiga penyimpangan asumsi klasik yang cepat terjadi dalam penggunaan model regresi, yaitu multikoliniearitas, heteroskedastisitas dan autokorelasi tidak bersifat BLUE (Best Linier Unblased Estimation), karenanya perlu dideteksi terlebih dahulu kemungkinan terjadinya penyimpangan tersebut dengan menggunakan:

\section{a. Uji Multikolinieritas}

Pengujian terhadap Multikolinieritas dilakukan untuk mengetahui apakah antara variabel bebas itu saling berkorelasi. Menurut Sugiyono (2001) ada hubungan linear di antara variabel-variabel bebas dalam model regresi. Jika hal ini terjadi maka sangat sulit untuk menentukan variabel bebas mana yang mempengaruhi variabel terikat. Untuk mendeteksi adanya multikolinieritas dalam penelitian ini maka digunakan korelasi matriks.

Dari perhitungan estimasi korelasi matrik dengan program SPSS versi 11, 0 dapat diketahui bahwa nilai VIF dari variabel kode etik pegawai (X1) sebesar 1,398 lebih kecil dari 5, maka tidak terjadi multikolinieritas antar variabel X1 dengan variabel Y. Nilai VIF dari variabel komite kode etik (X2) sebesar 1,426 lebih kecil dari 5, maka tidak terjadi multikolinieritas antar variabel X2 dengan variabel Y. Nilai VIF dari variabel remunerasi (X3) sebesar 1,143 lebih kecil dari 5, maka tidak terjadi multikolinieritas antar variabel X3 dengan variabel Y. Berdasarkan hasil perhitungan di atas dapat dilihat bahwa nilai VIF variabel bebas lebih kecil dari 5, sehingga tidak terjadi gejala korelasi antar variabel.

\section{b. Heteroskedastisitas}

Heteroskedastisitas adalah variasi residual tidak sama untuk semua pengamatan. Uji ini dimaksudkan untuk mengetahui apakah terjadi penyimpangan model karena varian gangguan berbeda antara satu observasi ke observasi yang lain. Cara yang dilakukan untuk mendeteksi terjadinya Heteroskedastisitas dalam varian error term suatu model regresi adalah dengan menggunakan metode Spearman Rank Correlation, apabila diperoleh r-hitung lebih kecil dari nilai kritis, berarti tidak terjadi penyimpangan dengan model regresi, demikian pula sebaliknya. Apabila nilai probabilitas dari residual lebih besar dari $\odot=0,05$, maka tidak terjadi gejala heteroskedastisitas begitu juga sebaliknya apabila nilai dari residual lebih kecil dari $\odot=0,05$, maka akan terjadi gejala heteroskedastisitas. 
Koefisien korelasi antara residu X1 adalah sebesar 0,147 dengan probabilitas 0,080 yang nilainya $>0,05$ sehingga dapat disimpulkan bahwa antara residu dengan X1 tidak terjadi heteroskedastisitas. Koefisien korelasi antara residu X2 adalah sebesar 0,197 dengan probabilitas 0,075 yang nilainya $>0,05$ sehingga dapat disimpulkan bahwa antara residu dengan X2 tidak terjadi heteroskedastisitas. Koefisien korelasi antara residu X3 adalah sebesar 0,142 dengan probabilitas 0,072 yang nilainya $>0,05$ sehingga dapat disimpulkan bahwa antara residu dengan X3 tidak terjadi heteroskedastisitas.

\section{c. Autokorelasi}

Menurut Algifari (1997) uji Autokorelasi dimaksudkan untuk mengetahui apakah terjadi korelasi antara anggota serangkaian data observasi yang diuraikan menurut waktu (time series) atau ruang (cross sectional). Hal ini mempunyai arti bahwa suatu tahun tertentu dipengaruhi oleh tahun berikutnya. Untuk menguji ada tidaknya Autokorelasi ini dapat dilakukan dengan menggunakan Watson statistik, yaitu dengan melihat koefisien korelasi Durbin Watson.

Berdasarkan hasil analisis regresi diketahui nilai Durbin Watson (DW) sebesar 1,851. Nilai DW terletak antara 1,55 sampai dengan 2,46 dengan kesimpulan tidak ada autokorelasi antar masing-masing variabel bebas, sehingga model regresi yang terbentuk dari nilai variabel terikat yaitu sensitivitas etika hanya dijelaskan oleh variabel bebas yaitu kode etik pegawai, komite kode etik dan remunerasi.

\section{d. Uji Normalitas}

Uji normalitas sebaran bertujuan untuk melihat normal atau tidaknya distribusi sebaran skor subjek pada suatu variabel yang dianalsis. Distribusi sebaran yang normal memiliki arti bahwa penelitian tergolong refresentatif atau dapat mewakili populasi yang ada, sebaliknya apabila sebaran tersebut tidak normal, maka disimpulkan bahwa subjek penelitian itu tidak refresentatif atau tidak dapat mewakili keadaan populasi yang sebenarnya, sehingga hasilnya tidak layak untuk digeneralisasikan pada populasi tersebut. Kaidah uji signifikan yang digunakan adalah jika p>0,05, maka tidak ada perbedaan antara sebaran skor subjek sampel penelitian dan sebaran skor subjek pada populasi (sebarannya dikatakan tidak normal). Uji normalitas menggunakan One-Sample Kolmogorov-Smirnov Test. Berdasarkan hasil analisis One-Sample Kolmogorov-Smirnov Test diketahui bahwa semua data variabel normal karena memiliki signifikansi $<0,05$.

\section{METODE ANALISIS DATA}

Metode analisis data yang digunakan dalam penelitian ini adalah analisis regresi linier berganda. Pemilihan alat statistik untuk menganalisis data ini, 
ditujukan untuk menjawab hipotesis yang telah diajukan. Dalam penelitian ini analisis data dilakukan dengan model. Model statistik tersebut yaitu:

$\mathrm{Y}=\alpha+\beta 1 \mathrm{X} 1+\beta 2 \mathrm{X} 2+\beta 3 \mathrm{X} 3+\varepsilon$.

Keterangan:

$\mathrm{Y}=$ Sensitivitas etika

$\alpha=$ konstanta

X1 = Kode etik pegawai

$\mathrm{X} 2$ = Komite kode etik

$\mathrm{X} 3=$ Remunerasi

$\beta 1-3=$ koefisien regresi

$\varepsilon=$ error term.

\section{ANALISIS DATA}

Hasil regresi linier berganda dari pengaruh variabel kode etik pegawai, komite kode etik dan remunerasi terhadap sensitivitas etika tax auditor ditunjukkan dalam tabel berikut ini:

Tabel 3 .

Hasil Regresi Linier Berganda

\begin{tabular}{|l|c|c|c|}
\hline \multicolumn{1}{|c|}{ Keterangan } & $\begin{array}{c}\text { Unstandardize } \\
\text { Coefficients Beta }\end{array}$ & Sig & t \\
\hline (Constant) & 1,388 & 4,260 & 0,000 \\
\hline Kode Etik Pegawai & 0,270 & 3,256 & 0,001 \\
\hline Komite kode etik & 0,266 & 4,643 & 0,000 \\
\hline Remunerasi & 0,095 & 2,961 & 0,014 \\
\hline $\begin{array}{l}\text { R2 }=0,321 \\
\text { F-hitung = 28,069 Sign }=0,000\end{array}$ \\
\hline
\end{tabular}

Sumber: Data primer diolah, 2010

Berdasarkan hasil analisis regresi pada tabel di atas dapat disusun persamaan regresi pengaruh variabel kode etik pegawai, komite kode etik dan remunerasi terhadap sensitivitas etika tax auditor sebagai berikut:

$\mathrm{Y}=1,388+0,270 \mathrm{X} 1+0,266 \mathrm{X} 2+0,095 \mathrm{X} 3+\mathrm{e}$

Keterangan

$\mathrm{Y}=$ Sensitivitas etika

$\mathrm{X} 1=$ Kode etik pegawai

$\mathrm{X} 2=$ Komite kode etik

X3=Remunerasi 
Dari persamaan hasil regresi tersebut dapat dilihat bahwa kode etik pegawai memiliki koefisien sebesar 0,270. Hal ini berarti setiap peningkatan variabelkodeetikpegawai sebesar $100 \%$ akan meningkatkan sensitivitasetika sebesar 27,0\%. Variabel komite kode etik memiliki koefisien sebesar 0,266. Hal ini berarti setiap peningkatan variabel komite kode etik sebesar $100 \%$ akan meningkatkan sensitivitas etika sebesar 26,6\%. Variabel remunerasi memiliki koefisien sebesar 0,095. Hal ini berarti setiap peningkatan variabel remunerasi sebesar 100\% akan meningkatkan sensitivitas etika sebesar 9,5\%. Berdasarkan nilai koefisien masing-masing variabel dapat diidentifikasi bahwa variabel yang dominan mempengaruhi sensitivitas etika adalah kode etik pegawai.

Besarnya nilai pengaruh tersebut ditunjukkan oleh nilai $\mathrm{R} 2=32,1 \%$ yang menunjukkan persentase pengaruh kode etik pegawai, komite kode etik dan remunerasi terhadap perubahan tingkat sensitivitas etika sebesar $32,1 \%$. Variabel lain yang menjelaskan variasi perubahan tingkat sensitivitas etika secara total selain kode etik pegawai, komite kode etik dan remunerasi sebesar $67,9 \%$.

Analisis berikut ini merupakan uji hipotesis yang bertujuan untuk menguji pengaruh variabel kode etik pegawai terhadap sensitivitas etika tax auditor. Sebagai dasar untuk menerima atau menolak hipotesis dilakukan pengujian hubungan kausal menggunakan analisis Regresi Linier berganda dengan cara membandingkan nilai probabilitas dengan taraf signifikansi sebesar 0,05 atau 5\%. Hipotesis yang diajukan sebagai berikut :

H1: Kode etik pegawai berpengaruh positif dan signifikan terhadap Sensitivitas etika Tax auditor di Lingkungan Kantor Wilayah DJP Jakarta khusus.

Untukmengujipengaruhvariabelkodeetik pegawaiterhadapsensitivitas etika tax auditor dilakukan dengan cara membandingkan nilai probabilitas t-hitung 0,001 <0,05. Dari hasil perbandingan tersebut dapat disimpulkan H1 diterima, yang berarti variabel kode etik pegawai berpengaruh positif dan signifikan terhadap sensitivitas etika tax auditor di Lingkungan Kantor Wilayah DJP Jakarta khusus. Semakin baik kode etik pegawai maka semakin tinggi tingkat sensitivitas etika tax auditor di Lingkungan Kantor Wilayah DJP Jakarta khusus, sebaliknya semakin buruk kode etik pegawai maka semakin rendah tingkat sensitivitas etika tax auditor di Lingkungan Kantor Wilayah DJP Jakarta khusus.

Analisis berikut merupakan uji hipotesis yang bertujuan untuk menguji pengaruh variabel komite kode etik terhadap sensitivitas etika tax auditor. Sebagai dasar untuk menerima atau menolak hipotesis dilakukan pengujian hubungan kausal menggunakan analisis Regresi Linier Sederhana dengan cara membandingkan nilai probabilitas dengan taraf signifikansi sebesar 0,05 atau 5\%. Hipotesis yang diajukan sebagai berikut : 
H2: Komite kode etik pegawai berpengaruh positif dan signifikan terhadap Sensitivitas etika Tax auditor di Lingkungan Kantor Wilayah DJP Jakarta khusus.

Pengujian pengaruh variabel komite kode etik terhadap sensitivitas etika tax auditor dilakukan dengan cara membandingkan nilai probabilitas t-hitung $0,000<0,05$. Dari hasil perbandingan tersebut dapat disimpulkan H2 diterima, yang berarti variabel komite kode etik berpengaruh positif dan signifikan terhadap sensitivitas etika tax auditor di Lingkungan Kantor Wilayah DJP Jakarta khusus. Semakin tinggi pengawasan dari komite kode etik maka semakin tinggi tingkat sensitivitas etika tax auditor di Lingkungan Kantor Wilayah DJP Jakarta khusus, sebaliknya rendah pengawasan dari komite kode etik maka semakin rendah juga tingkat sensitivitas etika tax auditor di Lingkungan Kantor Wilayah DJP Jakarta khusus.

Analisis selanjutnya merupakan uji hipotesis yang bertujuan untuk menguji pengaruh variabel kode etik pegawai terhadap sensitivitas etika tax auditor. Sebagai dasar untuk menerima atau menolak hipotesis dilakukan pengujian hubungan kausal menggunakan analisis Regresi Linier Sederhana dengan cara membandingkan nilai probabilitas dengan taraf signifikansi sebesar 0,05 atau 5\%. Hipotesis yang diajukan sebagai berikut :

H3: Remunerasi berpengaruh positif dan signifikan terhadap Sensitivitas etika Tax auditor di Lingkungan Kantor Wilayah DJP Jakarta khusus.

Pengujian pengaruh variabel remunerasi terhadap sensitivitas etika tax auditor dilakukan dengan cara membandingkan nilai probabilitas thitung 0,014<0,05. Dari hasil perbandingan tersebut dapat disimpulkan H3 diterima, yang berarti variabel remunerasi berpengaruh positif dan signifikan terhadap sensitivitas etika tax auditor di Lingkungan Kantor Wilayah DJP Jakarta khusus. Semakin baik sistem remunerasi maka semakin tinggi tingkat sensitivitas etika tax auditor di Lingkungan Kantor Wilayah DJP Jakarta khusus, sebaliknya semakin buruk sistem remunerasi maka semakin rendah tingkat sensitivitas etika tax auditor di Lingkungan Kantor Wilayah DJP Jakarta khusus.

Pengujian pengaruh variabel kode etik pegawai, komite kode etik dan remunerasi secara simultan terhadap sensitivitas etika menggunakan signifikansi uji-F. Berdasarkan analisis data diketahui F-hitung adalah 28,069 dengan tingkat signifikansi 0,000. Signifikansi F-hitung sebesar 0,000 lebih kecil dari probabilitas 0,05. Hal ini menunjukkan bahwa variabel bebas yang terdiri dari sikap kode etik pegawai, komite kode etik dan remunerasi secara simultan berpengaruh terhadap variabel terikat yaitu sensitivitas etika.

Kode etik disusun dan dikembangkan saat prinsiup etika diperlukan dalam dunia praktis serta dalam kebutuhan profesionalisme kerja (Freeman, 1996). Kode etik merupakan strategi untuk melembagakan etika dalam 
struktur dan kegiatan organisasi. Jika organisasi memiliki kode etik sendiri, ia mempunyai beberapa kelebihan dibandingkan dengan perusahaan yang tidak memilikinya. Kode etik dapat menjelaskan bagaimana anggota organisasi menilai tanggung jawab sosialnya. Kode etik berfungsi dalam merumuskan standar etis yang jelas dan tegas untuk semua pegawai dan jangkauan tanggung jawab sosial perusahaan. Semakin baik kode etik yang disusun maka semakin baik tingkat sensitivitas etika tax auditor di Lingkungan Kantor Wilayah DJP Jakarta khusus. Manfaat kode etik dapat dijelaskan sebagai berikut (Bertens, 2000), kode etik dapat meningkatkan kredibilitas suatu perusahaan karena etika telah dijadikan sebagai corporate culture. Kode etik pegawai berfungsi dalam merumuskan standar etis yang jelas dan tegas untuk semua pegawai dan jangkauan tanggung jawab sosial organisasi.

Komite Kode Etik berfungsi sebagai pengawas atas ketaatan pegawai DJP terhadap kode etik pegawai, komite berperan sebagai controller atas tindakan etis pegawai pajak. Alleyne et al (2006) mengemukakan bahwa komite audit berperan dalam pengawasan auditor dalam melakukan audit sehingga mencegah auditor untuk melakukan pelanggaran-pelanggaran. Dengan demikian semakin baik pelaksanaan sistem adminitrasi pajak modern maka semakin tinggi Sensitivitas etika tax auditor pada Lingkungan Kantor DJP. Semakin baik pelaksanaan komite kode etik maka semakin baik tingkat sensitivitas etika tax auditor di Lingkungan Kantor Wilayah DJP Jakarta khusus.

Etika merupakan sumber moral dalam berperilaku, individu yang tidak beretika cenderung melakukan tindakan kolusi dibandingkan yang memiliki etika. Sejalan dengan usaha untuk mencegah resiko godaan pemenuhan penghasilan, dalam sistem administrasi pajak modern ditetapkan remunerasi berupa pemberian tunjangan kegiatan tambahan dan diharapkan tax auditor di Lingkungan Kantor Wilayah DJP Jakarta Khusus akan berlaku etis. Santos et al (2004) menemukan bahwa pemberian imbalan atau tunjangan akan meningkatkan kinerja pegawai karena imbalan atau tunjangan akan mendorong pegawai untuk bertindak secara etis. Roman \& Munuera (2004) dalam penelitian juga menemukan bahwa semakin baik sistem kompensasi yang diberlakukan dalam organisasi akan meningkatkan etika pegawai.

Kompensasi merupakan bagian dari pengharapan pegawai dalam bekerja sebagai balas jasa atas pengabdian pegawai pada organisasi. Sesuai teori Maslow, dalam pemenuhan kebutuhan hidup sehari-hari pegawai membutuhkan sesuatu yang dapat digunakan sebagai alat pemenuhan kebutuhan hidup. Apabila imbalan atau reward mencukupi atas kebutuhan pegawai maka pegawai akan bekerja secara optimal sehingga kinerjanya meningkat. Dengan demikian semakin tinggi kompensasi maka semakin 
tinggi kinerja pegawai sebaliknya semakin rendah kompensasi maka semakin rendah kinerjanya. Kompensasi dapat berupa imbalan langsung dan tidak langsung. Kompensasi langsung dalam hal ini gaji dan sistem gaji merupakan balas jasa secara langsung pada pegawai berdasarkan pekerjaan yang dilakukan, sehingga cenderung berperilaku yang sesuai prosedur organisasi atau taat aturan yang etis.

\section{KESIMPULAN \& SARAN}

Berdasarkan analisis data diperoleh kesimpulan bahwa adiministrasi pajak modern yang dilihat dari kode etik pegawai, komite kode etik dan remunerasi berpengaruh positif dan signifikan terhadap sensitivitas etika tax auditor di Lingkungan Kantor Wilayah DJP Jakarta khusus. Semakin baik penerapan kode etik pegawai, komite kode etik dan remunerasi maka semakin tinggi tingkat sensitivitas etika tax auditor di Lingkungan Kantor Wilayah DJP Jakarta khusus, sebaliknya semakin buruk penerapan kode etik pegawai, komite kode etik dan remunerasi maka semakin rendah tingkat sensitivitas etika tax auditor di Lingkungan Kantor Wilayah DJP Jakarta khusus. Adiministrasi pajak modern yang diberlakukan memberikan kontribusi bagi sensitivitas etika tax auditor di lingkungan Kantor Wilayah DJP Jakarta khusus.

Berdasarkan kesimpulan yang diperoleh dari analisis data, penulis memberikan saran sebagai berikut:

Secara teoritis, hasil penelitian ini mendukung konsep pengaruh sistem administrasi pajak modern yang dilihat dari penerapan kode etik pegawai, komite kode etik dan remunerasi terhadap sensitivitas etika tax auditor. Bagi Kantor Wilayah DJP Jakarta khusus, secara menyeluruh sistem administrasi pajak modern berpengaruh terhadap sensitivitas etika tax auditor namun pengaruhnya termasuk kecil. Faktor yang dominan mempengaruhi sensitivitas etika tax auditor adalah kode etik pegawai sehingga faktor ini perlu dipertahankan sedangkan faktor numerasi perlu ditingkatkan karena faktor ini berpengaruh paling kecil dibandingkan faktor lainnya. Selain faktor kode etik pegawai, komite kode etik dan remunerasi, ada faktor lain yang mempengaruhi sensitivitas etika pegawai seperti orientasi etika dan komitmen organisasi (Khomsiyah dan Indriantoro 1997). Selain itu faktor demografi seperti gender, tingkat pendidikan, usia juga mempengaruhi sensitivitas individu (Rustiana, 2003).

\section{DAFTAR PUSTAKA}

Abimanyu, Anggito. (2004). “Wajib Pajak Belum Patuh" Http: /Fiskal.depkeu. go.id

Adams, L.B. Malane.,L.F dan James W. Jr. (1994). “Auditing: Ethical Reasoning in Confidentiality Dicisions", The CPA Journal 
Algifari, 1997, Statistik Induktif, Yogyakarta:UPP AMP YKPN

Alhusin, Syahri (2002), Aplikasi Statistik Praktis dengan SPSS.10 for Windows, Yogyakarta: J\&J Learning.

Alleyne, Philmore, Howard Michael \& D Greenidge (2006). "The Role of Audit Committees In Barbados". Corporate Governance Vol 6 No 5.

Ameen, JC. Gulfrey dan Mc Millan JJ. (1996). "Gender Differences in Determining the Ethical Sensitivity of Future Accounting Profesionals", Journal of Business Ethics. Vol 15

Bertens, (2000). Pengantar Etika Bisnis, Penerbit Kanisius, Yogyakarta.

Chua, F.C., M.H.B. Perera, dan M.R. Mathews, (1994). Integration of Ethics into Tertiary Accounting Programmes in New Zealand and Australia. Dalam Accounting Education for the 21st Century: the Global Challenge, Edited by Jane O. Burns dan Belvesd E.Needles Jr., Edition 1.Sn: International Association for Accounting Education and Research.

Cooper, Donald P dan P.S. Shindler (2001). Business Research Methods. 7th Edition, Boston, McGraw Hill.

Cooper, D.R. \& Emory, C.W,. (2000), Business Research Methods, Fifth Edition, Chicago: Rhichard D. Irwin, Inc.

Dessler, Gary, (1997), Manajemen Sumber Daya Manusia (terjemahan), Jakarta: Prenhallindo

Guzzetta.D., (1996). Developing an incentive system for PHO physicianns, Journal Healthcare Financial management (HFM). ISSN: 0735-0732 Vol: 50 Iss: 2 Date: Feb 1996 P: 50-55.

Handoko,T. Hani, (2000). Manajemen Sumber Daya Manusia. Edisi 2. Badan Penerbit Fakultas Ekonomi, Yogyakarta.

Husada, Jan. (1996). "Etika Bisnis dan Etika Profesi dalam Era Globalisasi" Makalah KNA-KLB IAI Semarang

Indarti, MG Kentris (2001). “Faktor-faktor yang mempengaruhi intensitas penggunaan sistem informasi" Jurnal Akuntansi dan Manajemen edisi Desember 2001

Indriantoro, Nur (2000). "Pengaruh komputer anxiety terhadap keahlian dosen dalam penggunaan komputer" Jurnal Akuntansi dan Auditing Indonesia Vol 4 no 2 Desember.

Khomsiyah, dan Nur Indriantoro. (1997). "Pengaruh Orientasi Etika Terhadap Komitmen dan Sensitivitas Etika Auditor Pemerintah di DKI Jakarta" Makalah dalam Simposium Nasional Akuntansi 1

Ludigdo dan Machfoedz, Mas'ud. (1999). “Persepsi Akuntan dan Mahasiswa tentang Etika Bisnis" Jurnal Riset Akuntansi Indonesia vol 2 no 1 juni

Madjid, Nurcholish, (1992), Ajaran Nilai Etis Dalam Kitab Suci dan Relevansinya Bagi Kehidupan Modern. Dalam Islam Doktrin dan Peradaban: Sebuah Telaah Kritis tentang Masalah Keimanan, 
Kemanusiaan, dan Kemodernan. Yayasan Wakaf Paramadina, Jakarta, Desember

Mariani, Merlin (2004). "Persepsi Perusahaan Perbankan di Palembang Terhadap Urgensi Komputerisasi Akuntansi" Jurnal Keuangan dan Bisnis Vol 2 no 1 maret 2004.

Nunnaly, Jum C. (1979). Psychometric Theory. McGraw-Hill:New Delhi.

Nuryatno, Muh, dan Synthia Dewi, (2001). Tinjauan Etika Atas Pengambilan Keputusan Auditor Berdasarkan Pendekatan Moral. Media Riset Akuntansi, Auditing \& Informasi. Vol 1 No3.

Radtke, R.R (2000). “The Effect of Gender and Setting on Accountants' Ethically Sensitive Decisions". Journal of Business Ethics.

Roman, Sergio \& Munuera, J Luis (2005). “Determinants and Consequences of Ethical Behaviour: An Empirical Study Of Slespeople". European Journal of Marketing Vol 39 No56.

Rustiana. (2003). "Studi Empiris novice accountant: Tinjauan Gender," Jurnal Studi Bisnis. vol 1 no 2

Santos, Monica F, Mike Bourne and H, Russell (2004). “Executive pay and performance Measurement Practices in the $\mathrm{UK}^{\prime}$ Measuring Business Excellence.

Sarwoto, (1991). Dasar-Dasar Organisasi Dan manajemen, Ghalia, Jakarta

Schuler,R.S., \& Huber, V.L., (1993). Personal end Human Resource Management, Minessota: West Publishing Company

Sekaran, Uma, (2003), "Research Methods for Business: A Skill Building Approach", second edition, John Willey dan Sons, Inc.,New York

Siagian, S.P., (1996). Manajemen Sumber Daya manusia. Edisi Kelima, Bumi Aksara Jakarta

Simamora, H., (1997). Manajemen Sumber Daya Manusia, Edisi ke 2, STIE YKP, Yogyakarta

Suandy, Erly. (2000). "Hukum Pajak". PT Salemba Empat, Jakarta

Sugiyono, (2001), Metode Penelitian Bisnis, Bandung : Alfabeta

Suseno, Franz Mafnis, (1997). Etika Dasar. Penerbit Kanisius, Yogyakarta.

Wijaya, Tony, (2005),"Pengaruh komputer anxiety terhadap keahlian penggunaan komputer," Jurnal Pendidikan Terbuka dan Jarak Jauh. Vol. 6, No 1.

Zekos, Georgios I. (2004). "Ethics Versus Corruption In Globalization ". Journal of Management Development. Vol 23 No 7 pp631-647.

Bisnis Indonesia, (2004). Kepatuhan Wajib Pajak Rendah. Bisnis Indonesia, Http:/Klikpajak.com/artikel

Sriwijaya Post, 25 Maret 2004. Kontribusi Pajak Bagi Daerah. 